\title{
CORRIGENDUM
}

\section{Association of low-density lipoprotein receptor polymorphisms and outcome of hepatitis $C$ infection}

\author{
BJW Hennig, S Hellier, AJ Frodsham, L Zhang, P Klenerman, S Knapp, M Wright, HC Thomas, \\ M Thursz and AVS Hill
}

Genes and Immunity (2007) 8, 707; doi:10.1038/sj.gene.6364444

Correction to: Genes and Immunity (2002) 3, 359-367. doi:10.1038/sj.gene.6363883

Since the publication of the above article, an error was discovered in the genotyping assay for the exon $8 \mathrm{~A} 370 \mathrm{~T}$ SNP at position 11429 (rs11669576). The P1 and P2 probe sequences for the detection of this SNP were designed incorrectly and end one base before the polymorphic site, similarly the first base of P3 does include the SNP site itself. A comparison with genotype/allele frequencies for this polymorphism in other Caucasian population ${ }^{1,2}$ shows that the frequency of the minor allele (A) was increased in our sample, indicating that the assay used in our study led to skewed results for this SNP. The authors apologize for this mistake.

\section{References}

1 Kotze MJ, Retief AE, Brink PA, Weich HF. A DNA polymorphism in the human low-density lipoprotein receptor gene. $S$ Afr Med J 1986; 70: 77-79.

2 Consortium IH. A haplotype map of the human genome. Nature 2005; 437: 1299-1320. 